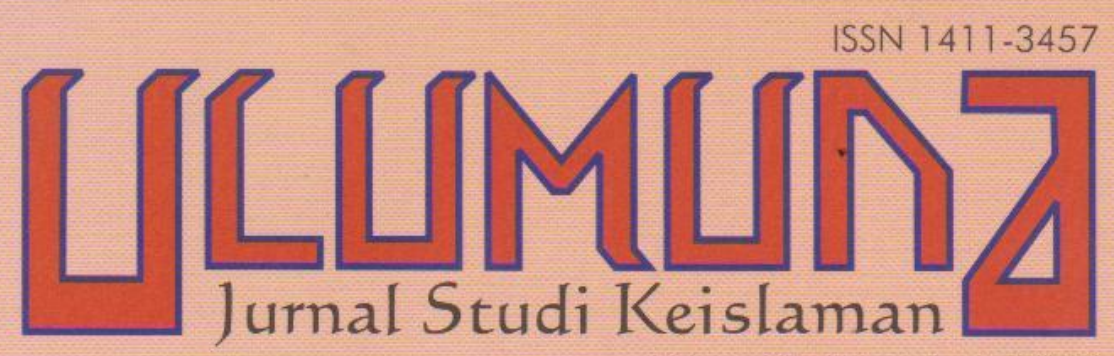

Volume XII• Nomor 1• Juni 2008

STUDI ANALITIS DIMENSI SACIFACT PENDIDIKAN ISLAM PADA MASA KEJAYAANNYA (750-1258 M) Abdul Fattah

AKTUALISASI MANUSIA VERSI AL-QUR'AN: ANTARA IDEALITAS DAN REALITAS PENDIDIKAN ISLAM Ismail Thoib

PENDIDIKAN ISLAM DAN PENCERAHAN SPIRITUALITAS: IKHTIAR MENJAWAB TANTANGAN POSMODERNISME Suparta

LESSON STUDY DALAM PEMBELAJARAN AGAMA ISLAM DI SEKOLAH UMUM Ahmad Munjin dan Khoirul Adib

STUDI PERUBAHAN KELEMBAGAAN DAN METODOLOGI PADA MADRASAH MODEL Taufik Churahman dan Musfigon POSISI PEREMPUAÑ
PERSPEKTIF ULAMA KLASIK
Baehaqi 


\section{PEDOMAN TRANSLITERASI}

\begin{tabular}{|c|c|c|c|}
\hline Arab & Latin & Arab & Latin \\
\hline 1 & $=$ & ف & $=\mathbf{f}$ \\
\hline ب & $=$ & ق & $=\mathrm{q}$ \\
\hline$\dot{H}$ & ts & ك & $=\mathbf{k}$ \\
\hline ج & $=$ & $J$ & $=1$ \\
\hline$\tau$ & $=$ & b & $=\mathrm{m}$ \\
\hline$\dot{\tau}$ & $=\quad \mathrm{kh}$ & $\dot{0}$ & $=\mathbf{n}$ \\
\hline$د$ & $=$ & و - - - 1 & $=\mathbf{w}$ \\
\hline$\dot{j}$ & $\mathrm{dz}$ & • & $=h$ \\
\hline$\jmath$ & $=$ & $\&$ & $=$, \\
\hline j & $=$ & ي & $=y$ \\
\hline س س & $=$ & & \\
\hline ش & $=$ & \multirow{2}{*}{\multicolumn{2}{|c|}{$\begin{array}{l}\text { Untuk Madd } \\
\text { dan Diftong }\end{array}$}} \\
\hline ص & sh & & \\
\hline ض & dl & i & $=$ â (a panjang) \\
\hline b & th & إين & $=\hat{\mathbf{1}}(\mathbf{i}$ panjang) \\
\hline ظ & $\mathrm{zh}$ & أوْ & $=\quad \hat{\mathbf{u}}$ (u panjang) \\
\hline$\varepsilon$ & $=$ & 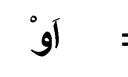 & $=a w$ \\
\hline$\dot{\varepsilon}$ & $=g h$ & آين & $=$ ay \\
\hline
\end{tabular}




\section{ISI}

TRANSLITERASI

ANTARAN

UTAMA

Abdul Fattah

Studi Analitis Dimensi Sacifact Pendidikan Islam pada Masa Kejayaannya $(750-1258 \mathrm{M}) \bullet 1-28$

Ismail Thoib

Aktualisasi Manusia Versi Al-Qur'an:

Antara Idealitas dan Realitas

Pendidikan Islam • 29-46

Suparta

Pendidikan Islam dan Pencerahan

Spiritualitas: Ikhtiar Menjawab Tantangan

Posmodernisme • 47-66

Ahmad Munjin Nasih Lesson Study dalam Pembelajaran

dan Khoirul Adib Pendidikan Agama Islam

di Sekolah Umum • 67-88

Taufik Churahman Dinamika Pendidikan Islam: Studi

dan Musfiqon

Perubahan Kelembagaan dan Metodologi

pada Madrasah Model • 89-106

LEPAS

Mutawalli Pembaruan Hukum Islam:

Menimbang Tawaran Pemikiran

'Abd al-Lâh al-Na'îm • 107-128

Baehaqi Posisi Perempuan

Perspektif Ulama Klasik • 129-142

Ahmad Sulhan Islam Kontemporer: Antara Reformasi

dan Revolusi Peradaban • 143-156

Ahmad Choirul Rofiq Menilai Kompetensi al-Mâturîdî di Bidang

Tafsir al-Qur'an • 157-182

ULAS BUKU

Yayuk Fauziyah Menyingkap Kuasa Maskulinitas di Balik

Tabir Feminitas Wanita Jawa • 183-200

INDEKS 


\title{
MENYINGKAP KUASA MASKULINITAS DI BALIK TABIR FEMINITAS WANITA JAWA
}

\author{
Yayuk Fauziyah*
}

\author{
Judul: Kuasa Wanita Jawa \\ Penulis: Christina S. Handayani dan Ardian Novianto \\ Penerbit: LKiS, Yogyakarta, 2004 \\ Tebal: 236 halaman
}

BERKELAMIN wanita bukanlah 'pilihan' hamba-Nya. Tak ada seorang pun yang berhak menentukan dirinya menjadi laki-laki atau wanita karena itu adalah "titah" dari Sang Kuasa. Oleh karena itu tidaklah mungkin Sang Pencipta akan bertindak tidak adil dengan keduanya. Menjadi sangat tidak arif jika di antara keduanya, laki-laki dan perempuan ada yang mengklaim sepihak sebagai superior atau menjadi "the self" dan yang lain menjadi inferior atau menjadi "the other", karena hal itu juga merupakan sebentuk ketidakadilan yang sama sekali tidak diinginkan oleh Sang Kuasa. Ironisnya, "hijab" yang membedakan antara lakilaki dan wanita alias maskulinitas dan feminitas ${ }^{1}$ itu tetap ada

*Penulis adalah dosen Universitas Muhammadiyah Sidoarjo, Jawa Timur. email: yayuk_fauziyah@yahoo.com

${ }^{1}$ Penulis mendasarkan makna 'maskulinitas' dan 'feminitas' menurut Harding dan Shiva. Ideologi feminitas adalah yang berciri kedamaian, keselamatan, kasih, dan kebersamaan. Sedangkan ideologi maskulinitas memiliki karakter persaingan, dominasi, eksploitasi, dan penindasan. Lihat Harding Susan, The Science Question and Feminism (Itacha: Cornell University, 1986). Lihat juga Vandana Shiva, Staying Alive (London: Zed Books, 1986). Lihat juga Mansour Fakih, Analisis Gender dan Transformasi Sosial (Yogyakarta: INSIST Press, 2005), 104-5. 
dalam aplikasinya, sehingga seringkali labelisasi terhadap wanita sebagai "sub-ordinat" dari kaum laki-laki bukanlah hal yang semu dalam sejarah. Parahnya dan lebih menyedihkan lagi, noktah yang tertoreh dalam riwayat kehidupan wanita itu belum usai hingga saat ini.

Wanita dalam perannya, sebenarnya punya andil penting dalam berbagai aspek kehidupan, terutama dalam kebijakan politik. Namun, peran ini sering diingkari oleh kaum Asianis laki-laki. Begitulah yang dikatakan oleh M. Stivens M (1991) dalam penelitiannya tentang Asia "Why Gender Matters in Southeast Asian Politic". Hal ini dikarenakan tradisi Asia yang memihak ideologi bahwa dunia 'publik' adalah dominasi laki-laki saja, sedangkan dunia "privat" adalah dunia wanita. ${ }^{2}$ Pembagian seperti ini tidaklah relevan jika diterapkan pada masyarakat Jawa, karena dalam masyarakat Jawa wanita terbiasa dengan peran 'privat' sekaligus peran 'publik'. Hal ini seperti yang terjadi pada masyarakat Jawa pedagang dan petani, di mana wanita mengurus rumah tangga (domestik) sekaligus mencari nafkah (ekonomi-publik). ${ }^{3}$

Wanita dalam masyarakat Jawa berperan bukan hanya di sektor ekonomi-publik saja, melainkan juga dalam sektor politik-

2Di samping tradisi ideologi yang menganggap wanita itu hanya punya tugas 'privat' dan laki-laki bertugas di 'publik', dan setelah Islam masuk di Indonesia, juga masih ada anomali dari perspektif agama yang cenderung memarjinalkan wanita. Wanita dianggap sebagai manusia skunder karena diciptakan dari tulang rusuk Adam yang merupakan manusia primer. Pandangan ini menjadi dasar asumsi bahwa wanita merupakan sub-ordinasi dari laki-laki. Ajaran keagamaan yang seperti ini berkembang disebabkan oleh satu kenyataan bahwa ajaran agama itu dirumuskan dan disebarluaskan dalam struktur masyarakat patriarki. Lihat Nana Nurliana Soeyono "Wanita Sebagai Pemimpin: Suatu Tinjauan Historis" dalam Wanita Dalam Masyarakat Indonesia: Akses, Pemberdayaan, dan Kesempatan, ed. Atha Mudzhar (Yogyakarta: Sunan Kalijaga Press, 2001), 283.

${ }^{3}$ Christina S. Handayani dan Ardhian Novianto, Kuasa Wanita Jawa (Yogyakarta: LkiS, 2004), 6-7. 
publik, ${ }^{4}$ seperti halnya istri presiden RI yang kedua, yaitu Siti Hartinah Soeharto. Dalam perspektif umum ia adalah wanita yang tidak punya kesempatan meraih pendidikan hingga jenjang yang tinggi. Pendidikannya hanya lulusan SMP zaman Belanda (Holland Indianhe School). Hal itu tidak sejajar dengan jabatan suaminya yang saat itu menjadi presiden dan kepala negara, ternyata hanya dengan satu kalimat dapat menentukan kebijakan pemerintah, misalnya keterkaitan Tien Soeharto dengan pembangunan Taman Mini Indonesia Indah (TMII). Berbeda dengan Hillary Clinton yang seorang pengacara lulusan Yale Law School tidak mungkin mempengaruhi proses penentuan kebijakan pemerintah di Amerika Serikat, meskipun waktu itu ia adalah istri dari Bill Clinton (Presiden Amerika Serikat periode tahun 1993-1996). ${ }^{5}$

Berdasarkan fenomena kaum wanita, terutama dalam kultur Jawa tersebut, penelitian dalam buku Kuasa Wanita Jawa ini, Christina dan Ardhian ingin membahas tentang kekuasaan wanita di Indonesia, terutama pada wanita Jawa. Fokusnya

${ }^{4}$ Setelah penulis telusuri, peran wanita Jawa dalam politik publik bisa diindikasikan sejak tahun $674 \mathrm{M}$ yaitu abad VII M. Menurut catatan orang Cina, rakyat kerajaan Holing (yang dimaksud adalah Kalinga di Jawa Tengah) menobatkan seorang wanita sebagai ratu dengan gelar Ratu His-Mo (Sima). Diceritakan Ratu Sima adalah ratu yang sangat adil, tidak pandang bulu dalam memberi hukuman baik kepada anaknya sendiri. Di samping itu, diceritakan juga bahwa Kerajaan Majapahit di Jawa Timur juga pernah dipimpin oleh seorang raja wanita selama 22 tahun, ketika Raja Jaya Negara meninggal pada tahun 1328 tanpa meninggalkan putra mahkota. Maka adiknya seorang putri diangkat untuk menggantikannya dengan gelar Tribuwanatunggadewi Jayawisnuwardhani. Pada tahun 1350-an ia mengundurkan diri dan pemerintahannya digantikan oleh putranya yang bernama Hayam Wuruk. Raja Hayam Wuruk ini terkenal sebagai salah satu raja besar yang dibantu oleh Patih Gajah Mada yang berhasil meluaskan kekuasaanya ke seluruh Nusantara. Pada akhir kekuasaan Majapahit (antara tahun 1429-1445) ada seorang ratu lagi memerintah, yaitu Ratu Suhita. Lihat Soeyono "Wanita..., 281.

${ }^{5}$ Novianto, Kuasa ..., 3-4. 
adalah bagaimana wanita Jawa yang melalui pola relasi dan interaksi yang dikembangkannya dalam kultur Jawa mempengaruhi proses-proses pengambilan keputusan, sehingga masalah gender dan kepemimpinan ini pun dapat dipelajari melalui budaya Jawa.

Penelitian yang dilakukan oleh Christina dan Ardhian adalah Desa Kluthuk di Kabupaten Bantul yang masih termasuk wilayah Propinsi Daerah Istimewa Yogyakarta. Masyarakat desa ini masih mempunyai pemahaman yang cukup kental tentang hubungan antara Kraton Mataram dan Ratu Kidul yang sarat dengan simbol-simbol kekuatan atau kekuasaan Jawa. Mereka juga masih memegang keyakinan-keyakinan tradisional yang kental yang menggambarkan masih kuatnya keterikatan mereka dengan nilai-nilai tradisional budaya Jawa, sebagaimana terlihat dalam perilaku warga. ${ }^{6}$

Sebagaimana diketahui, daerah Kabupaten Bantul menyimpan situs-situs kerajaan Mataram, seperti makam para raja di Imogiri dan Petilasan di Parangtritis. Beberapa kali daerah Bantul telah dipilih sebagai lokasi Kraton oleh para Raja Mataram seperti Kota Gede dan Pleret. Sementara itu, kota Yogyakarta sendiri merupakan pusat kebudayaan Jawa. Pengaruh Kraton Yogyakarta dan sultan masih cukup besar bagi rakyat Yogyakarta. Alasan yang tak kalah penting adalah peneliti mengenal masyarakat dan daerah ini dengan baik. ${ }^{7}$

Penelitian ini merupakan penelitian deskriptif-eksploratif yang bertujuan untuk menyusun sebuah konstruksi teoritis dengan pendekatan kualitatif model behaviorisme sebagai basis analisis utama. Disebut sebagai penelitian deskriptif, karena peneliti ingin mengukur secara cermat terhadap fenomena sosial tertentu, yaitu kekuasaan wanita Jawa. Peneliti mengembangkan konsep dan menghimpun fakta, namun tidak melakukan

'Ibid., 21-2.

${ }^{7}$ Ibid. 
hipotesis. ${ }^{8}$ Mengenai penelitian eksploratif, seperti diketahui, jenis penelitian ini memiliki sifat terbuka, sehingga belum memiliki hipotesis. ${ }^{9}$ Dalam penelitian eksploratif, menurut Jacob Vredenbergt, peneliti mencari hubungan di antara gejala-gejala sosial dan berusaha menjelaskan hubungan tersebut dengan menggali data. Oleh karena itu, jenis penelitian ini berusaha untuk memperluas dan mempertajam dasar empiris (dengan kajian lapangan) mengenai hubungan antara gejala-gejala yang sedang diteliti. ${ }^{10}$

Adapun metode konstruktif teoritis ini dimaksudkan sebagai suatu skema atau struktur atau gambar yang tidak merupakan kesimpulan induktif dari data tertentu, tidak juga hasil suatu deduksi, tetapi dibangun atas dasar kepastian intuitif dengan tujuan untuk mencapai kejelasan logis, dengan harapan bahwa konstruksi itu akan membantu untuk memahami sesuatu dengan lebih baik. ${ }^{11}$

Menurut peneliti alasan menggunakan metode ini adalah keterbebasan peneliti dari tekanan untuk harus membuktikan bahwa "kekuatan wanita Jawa" itu memang ada atau pernah ada atau pernah diketemukan dan sebagainya. Dengan metode ini juga peneliti sekaligus ingin membangun sebuah "tipos ideal", yang menurut Max Weber, secara sempurna memuat ciri-ciri khas dari satuan-satuan dalam sejenis karena bebas dari realitas yang tidak pernah murni, konsisten, atau logis. Kegunaan "tipos ideal" terletak pada kemurnian paham yang mengizinkan kita berbicara dengan jelas, sedangkan terhadap realitas empiris,

${ }^{8}$ M. Singarimbun, "Metode dan Proses Penelitian" dalam Masri Singarimbun dan Sofian Effendi, Metode Penelitian Survai (Jakarta: LP3ES, 1989), 4-5.

${ }^{9}$ Ibid., 4.

${ }^{10}$ Ibid., 31.

${ }^{11}$ Frans Magnis Suseno, Etika Jawa (Jakarta: Gramedia Pustaka Utama, 1996), 4-5. 
"tipos ideal" tidak merupakan cerminan atau saringannya, tetapi titik acuan atau tantangan. ${ }^{12}$

Peneliti juga mengungkap kerugian dalam menggunakan metode ini yaitu terletak pada bahaya bahwa kaitannya dengan realitas sosial-empiris dapat semakin menipis, bahkan hilang. Untuk mengimbangi bahaya itu, sebagai kontrol konstruksi teoritis tentang "kekuasaan wanita Jawa", maka studi ini memanfaatkan data ilmu-ilmu sosial empiris tentang masyarakat Jawa, di samping peneliti juga melakukan pengambilan data langsung di lapangan. Namun demikian, hal itu tidak mengubah kenyataan bahwa bagaimanapun juga "kekuasaan" wanita Jawa, orang Jawa, dan masyarakat Jawa dalam penelitian ini tidak langsung menunjuk pada masyarakat Jawa yang nyata-nyata ada, atau pernah ada atau untuk sebagian ada.

Pendekatan kualitatif model behavioralisme dipilih oleh peneliti karena fokus perhatian penelitian ini bukan pada kelembagaan politik formal, melainkan lebih menfokuskan pada kaitan antara struktur politik dan masyarakat. ${ }^{13}$ Selanjutnya pendekatan ini lebih banyak mengkaji interaksi antara anggotaanggota masyarakat (baik dalam kelompok maupun secara perorangan dengan pembuat keputusan, termasuk bagaimana pendapat politik dibentuk, bagaimana keputusan diperoleh, serta cara-cara yang dipelajari orang mengenai kejadian-kejadian politik. $^{14}$

Di samping itu, peneliti juga menggunakan metode heuristik ${ }^{15}$, terutama model struktur semantik untuk menganalisis kerangka berpikir historis dan budaya Jawa sebagai ideologi. Metode ini merefleksikan hubungan-hubungan

${ }^{12}$ Novianto, Kuasa ...,19.

${ }^{13}$ H. Eckstein, dalam F. N. Kerlinger, Asas-Asas Penelitian Behavioral (Yogyakarta: Gadja Mada University Press, 1986) 660-8.

${ }^{14}$ Novianto, Kuasa..., 19.

${ }^{15}$ Heuristik adalah menyediakan bantuan dalam menemukan kebenaran atau pemecahan masalah. Lihat Ibid..., 21. 
semantik antara objek-objek yang tercakup dalam masalah dan untuk menafsirkan kembali nilai-nilai yang terkandung dalam ideologi tersebut. Metode hermeneutik juga dilakukan untuk mengungkap simbol-simbol yang ditemukan dalam unsur-unsur budaya Jawa, terutama penafsiran yang bertujuan untuk menjelaskan teks baik objektif (gramatikal kata-kata dan variasivariasi historisnya) maupun subjektif (maksud yang mengungkapkan).

\section{Fenomena Wanita Melayu Yang Terabaikan}

Wanita Melayu, ${ }^{16}$ sebenarnya secara tradisional aktif. Sejarah kehidupan bangsa mencatat bahwa wanita memegang peranan penting bahkan utama dalam bidang politik, wanita Indonesia sudah berperan di bidang politik jauh sebelum kolonialisme Barat. Aceh bahkan pernah diperintah oleh empat raja wanita, berturut-turut; Sultanah Sri Ratu Alam Safiatuddin Johar (16411675), Sultan Noer al-Alam Nakiat al-Din Shah (1675-1678), Sultan Inajat Syah Zakiat al-Din (1678-1688), dan yang terakhir adalah Sultan Kumalat Syah (1688-1699). ${ }^{17}$

Kesaksian-kesaksian peran wanita dalam politik bahkan bisa dijumpai di Jawa, tepatnya pada awal kerajaan-kerajaan Jawa. Salah satunya terdapat dalam kisah Wangsa Isyana, yang kemudian keturunannya mendirikan kerajaan Singashari dan kerajaan Majapahit. Kerajaan Singashari dengan Ken Dedes sebagai tokohnya, memperlihatkan bagaimana seorang wanita menjadi dalang bagi peralihan kekuasaan dari Tunggul Ametung ke Ken Arok. Ken Dedes menjadi otak yang menyusun strategi untuk memperlancar Ken Arok untuk menduduki kekuasaan Tunggul Ametung (saat itu menjadi suaminya) sebagai penguasa Tumapel. Keturunan Ken Dedes dengan Tunggul Ametung

16Melayu yang dimaksudkan di sini adalah satu rumpun yang tinggal di kawasan Asia Tenggara, dalam hal ini termasuk suku Jawa. Lihat Ibid., 29.

${ }^{17}$ Novianto, Kuasa..., 31 
melahirkan Sri Kartanegara (Raja Singashari, 1272-1292), dan keturunan Ken Dedes dengan Ken Arok melahirkan raja pertama Majapahit yaitu Raden Wijaya (1293-1309). Pada zaman Majapahit ini kemudian muncul sejumlah nama tokoh wanita yang penting yaitu Rajapatri (ibu dari Ratu Thribhuwana). ${ }^{18}$

Tak hanya berhenti di situ, Nyonya Suhartina Soeharto (istri presiden Soeharto) sebagaimana dijelaskan di atas, adalah sosok istri presiden yang banyak mempengaruhi presiden, terutama dalam mengambil keputusan publik. Di samping ide pembangunan Taman Mini Indah Indonesia yang banyak berasal dari Tien Soeharto, rumor lain yang berkembang adalah pembangunan Taman Candi Prambanan yang dilakukan oleh Soeharto tanpa melaului rapat APBD di DPRD sebagai badan legislatif. Fenomena ini menunjukkan betapa besar pengaruh Tien Soeharto terhadap kebijakan pemerintah (badan ekskutif) tanpa melalui prosedur formal (dengan persetujuan badan legislatif). ${ }^{19}$

Penjelasan di atas menggambarkan implikasi wanita Indonesia dalam peran publik yang bisa dianggap serius, namun masih ada segudang pertanyaan yang perlu dijawab "mengapa gender menjadi masalah dalam politik di Asia Tenggara" bahkan "mengapa gender tidak pernah dibicarakan dalam ilmu politik di kawasan ini". Ada kecenderungan bahwa lingkungan domestik dimanipulasi sedemikian rupa oleh penguasa atau pemerintah, sehingga meskipun sebenarnya berpengaruh besar terhadap publik, ia justru diturunkan oleh dogma-dogma publik. Misalnya tak jarang organisasi-organisasi wanita terbentuk bukan dari suatu gerakan wanita, melainkan diciptakan oleh para penguasa politik untuk mencapai tujuan politik tertentu. Selama ini juga tidak pernah memasukkan unsur-unsur feminitas seperti kelembutan, kepekaan, dan cinta. Akibatnya wanita yang

${ }^{18}$ Ibid., 30-1.

${ }^{19}$ Ibid., 37. 
mempunyai ciri feminim lebih menonjol merasa tidak kompeten untuk terlibat dalam bidang politik formal. Hal ini ditengarai oleh peneliti adanya kurangnya kajian psikologi tentang fenomena wanita di Indonesia yang secara tidak langsung menyebabkan kesalahpahaman dan kurang tergalinya potensi dan kekuatan wanita, terutama di bidang politik. ${ }^{20}$

Jauh sebelumnya, persoalan gender ini muncul diakibatkan konsep paternalistik yang secara formal hadir dalam pembagian peran laki-laki dan wanita. Konsep paternalistik itu memandang bahwa istri adalah konco wingking. Asal mulanya wanita menjadi konco wingking ini karena dipengaruhi oleh konsep agama Islam dan Kristen, yaitu ketika Tuhan menciptakan manusia pertama yang diciptakan terlebih dahulu adalah Adam, sesudah itu baru Hawa yang diciptakan dari rusuk Adam sebelah kiri. Dengan demikian, intinya adalah wanita derajatnya lebih rendah dari lakilaki. Seumpama tangan mereka adalah tangan kirinya, dan badan wanita adalah bagian pantatnya. ${ }^{21} \mathrm{Hal}$ ini seperti yang ditegaskan oleh Ester Boserup bahwa wanita Melayu sebenarnya secara tradisional itu aktif, namun karena kedatangan Islam dan pengaruh dari Inggris dan Belanda membantu menciptakan pola peran wanita yang lebih rendah dari laki-laki. ${ }^{22}$

\section{Kekuasaan Wanita Jawa}

Kekuasaan wanita Jawa adalah kemampuannya untuk mempengaruhi, menentukan, bahkan untuk mendominasi suatu keputusan (baca: kemampuan maskulinitas). Kemampuan wanita dalam kekuasaan tersebut itu merupakan sebuah proses adaptasi, pemaknaan kembali, hingga strategi diplomasi. ${ }^{23}$ Ada tiga konsep yang perlu dibahas dalam penjelasan selanjutnya yaitu; konsep

\footnotetext{
${ }^{20}$ Ibid., 6-7.

${ }^{21}$ Ibid., 118.

${ }^{22}$ Ibid.

23Ibid., 25.
} 
kekuasaan Jawa, karakteristik wanita Jawa, dan upaya memperoleh kekuasaan.

\section{Konsep Kekuasaan Jawa}

Keeler menyatakan bahwa kekuasaan pemimpin di Jawa tergantung bukan hanya pada kekuasaan yang dipaksakan dan birokratis, melainkan yang penting justru pada bagaimana pemimpin itu memenuhi citra ideal sebagai sosok teladan, yaitu seorang pemimpin yang berjiwa kuat, memikat, dan penuh teladan dengan sifat baik. ${ }^{24}$ Namun, menurut peneliti bahwa budaya Jawa tidak dapat dibatasi hanya pada ide tentang kekuasaan. Sebaliknya ide tentang kekuasan tidak dapat dibatasi hanya pada masalah keteladanan.

Konsep kekuasaan Jawa berbeda dengan konsep kekuasaan Barat. Perbedaan di antara keduanya adalah; (1) kekuasaan Barat perlu legitimasi, sedangkan kekuasan Jawa tidak perlu legitimasi, (2) kekuasan Barat bersifat heterogen yang dapat bersumber dari kekayaan, status sosial, jabatan formal, organisasi, senjata, populasi, dan sebagainya. Sedangkan kekuasaan Jawa bersifat homogen yang hanya merupakan ungkapan realitas yang sama berasal dari sumber yang sama dan berkualitas sama. Kekuasaan di tangan satu individu maupun kelompok adalah sama dengan yang berada di tangan individu atau yang lain, (3) kekuasaan Barat bersifat terbatas karena dikondisikan langsung oleh perkembangan teknologi, sedangkan kekuasaan Jawa bersifat tidak terbatas karena kekuasaan tidak terbatas pada teknologi tetapi kekuasaan yang terdapat dalam semesta itu dipandang bersifat konstan, dan (4) kekuasaan Barat bersifat abstrak, yaitu kekuasaan adalah gejala yang khas antarmanusia, sedangkan kekuasaan Jawa itu bersifat konkret, ada dengan sendirinya tanpa harus ada keterlibatan manusia. ${ }^{25}$

${ }^{24}$ Ibid., 94.

${ }^{25}$ Ibid., $98-100$ 
Pendidikan dalam kultur Jawa selalu menuntut seorang anak untuk mampu menahan dorongan hati atau menunda pemuasan dorongan hati. Pertama-tama anak belajar untuk merasa "wed?" terhadap orang yang harus dihormati. Kemudian anak diajar untuk merasa "isin". Belajar untuk "ngerti isin" (tahu malu), kemudian "duwe isin" (punya malu) adalah langkah pertama yang mengarah kepada kepribadian yang matang. Di samping itu adalah "sungkan" yaitu rasa hormat yang sopan terhadap atasan atau sesama yang belum dikenal. Dan langkah selanjutnya adalah pendidikan rukun. ${ }^{26}$

Konstruksi kultur kekuasaan Jawa cenderung kearah feminitas, dan sudah ada sejak zaman Hindu. Adapun feminitas yang dimaksud adalah feminin menurut Jungian, yaitu kesediaannya untuk menderita. Hal ini pun tampak dalam kecenderungan asketisme orang Jawa, yaitu tatkala mereka berusaha untuk menguasai nafsu-nafsunya dengan laku tapa. Semangat asketisme ini juga dimaksudkan untuk membebaskan diri dari egoisme (pamrih) atau sepi ing pamrih. Sifat tanpa pamrih itu biasanya melekat pada wanita. Sebaliknya sifat pamrih (egois) itu merupakan ciri maskulin yang biasanya melekat pada laki-laki. Hal ini dikarenakan laki-laki Jawa tidak dibiasakan menahan diri dan mengalah sebagaimana wanita. Dalam budaya yang bersifat paternalistik, laki-laki memilki kedudukan yang istimewa. Kelak mereka akan menjadi pemimpin keluarga, sehingga keinginan dan harapanya selalu diusahakan untuk dipenuhi, akibatnya mereka tidak biasa untuk menahan diri dan mengalah dibandingkan wanita. ${ }^{27}$

Di sampinng itu ada dimensi feminin lain yaitu; sabar, nrima, dan ikhlas. Sabar adalah mempunyai nafas panjang dalam kesadaran bahwa pada waktunya nanti nasib yang baik akan tiba. Nrima adalah menerima segala apa yang mendatangi kita, tanpa

${ }^{26}$ Ibid., 192

${ }^{27}$ Ibid.,178-180 
protes dan pemberontakan. Sifat nrima ini menuntut kekuatan untuk menerima apa yang tidak bisa dielakkan tanpa membiarkan diri dihancurkan olehnya. Sedangkan ikhlas adalah "bersedia". Sikap ini memuat kesediaan untuk melepaskan individualitas sendiri dan mencocokkan diri ke dalam keselarasan agung alam semesta sebagaimana yang sudah ditentukan. Begitu pula sikap orang yang mempunyai kekuasaan, dikatakan bahwa semakin besar kekuasaan seseorang, maka semakin dia bersikap halus. Konsep halus dalam kultur Jawa sangat menggambarkan feminitas seperti bertutur kata halus, hangat, pengedalian diri yang kuat, berperasaan halus, memahami orang lain, peka, dan kalem (tenang). ${ }^{28}$

\section{Karakteristik Wanita Jawa}

Sebagaimana dijelaskan di atas, bahwa konsep kekuasaan Jawa cenderung ke arah feminitas. Adapun dimensi feminitas sebagaimana yang didefinisikan oleh Jungian melekat pada karakteristik wanita Jawa. ${ }^{29}$ Karakter wanita Jawa sangat identik dengan kultur Jawa, seperti bertutur kata halus, tenang, diam atau kalem, tidak suka konflik, mementingkan harmoni, menjunjung tinggi nilai keluarga, mampu mengerti dan memahami orang lain, sopan, pengendalian diri tinggi atau terkontrol, daya tahan untuk menderita tinggi, memegang peranan secara ekonomi, dan setia atau loyalitas tinggi. ${ }^{30}$

Seperti dikemukakan oleh peneliti, bahwa di dusun Kluthuk ini wanita Jawa yang selain mempunyai ketahanan psikis tinggi juga mempunyai fisik yang kuat. Mereka terbiasa bekerja keras secara fisik, misalnya mencari rumput untuk pekan ternak, memanggul padi hasil panen, menggendong dodolan, dan masih harus berjalan jauh ke pasar. Pada umumnya wanita Jawa

${ }^{28}$ Ibid., 181-2

${ }^{29}$ Lihat penjelasan Jungian tentang feminitas pada halaman 8

${ }^{30}$ Novianto, Kuasa..., 130. 
mempunyai kebiasaan untuk bangun paling pagi dan tidur paling akhir, sementara sepanjang hari mengurus rumah. Meski tetap harus berjualan di pasar. Ia juga menyiapkan makan untuk suami dan anak-anaknya, jarang ditemukan wanita Jawa yang manja dan tidak mau bekerja. ${ }^{31}$

Seorang wanita Jawa dapat menerima segala situasi bahkan yang terpahit sekalipun. Mereka paling pintar memendam penderitaan dan pintar pula memaknainya. Mereka kuat dan tahan menderita, sebagaimana digambarkan dalam pengakuan Pariyem di desa Kluthuk yang menghadapi kelakuan suaminya yang menyakitkan, tetapi istri tetap menghormati dan menghargainya. ${ }^{32}$

\section{Upaya Wanita Jawa Memperoleh Kekuasaan}

Setelah kita memahami bahwa konsep kekuasaan Jawa cenderung ke arah feminitas, dan dimensi feminitas ini melekat pada karakteristik wanita Jawa, maka tidak menutup kemungkinan di Jawa sebenarnya kekuasaan itu lebih didominasi wanita, yaitu makna kekuasaan wanita Jawa yang tentunya berbeda dengan makna kekuasaan Barat. Hal ini bisa dibuktikan dengan contoh-contoh keterlibatan Tien Soeharto (istri presiden Soeharto) dalam kuasanya terhadap suaminya Soeharto dalam pengambilan keputusan publik. Dan yang perlu dicatat bahwa kuasa Tien Soeharto adalah kekuasaan yang tidak ada legitimasi, namun istri presiden tersebut bisa mendominasi secara konkret, baik dalam fungsi privat maupun publik.

Wanita Jawa bisa mempunyai kekuasaan dikarenakan konstruksi kultur kekuasaan Jawa yang cenderung feminin. Dan kultur yang demikian ini secara alami membentuk sebuah kemampuan untuk mendominasi atau memenangkan wanita

${ }^{31}$ Ibid., 131.

${ }^{32}$ Lihat penjelasan atau paparan cerita yang ditulis peneliti dalam Novianto, Kuasa..., 131-4. 
Jawa untuk bisa berperan lebih depan dalam menentukan sebuah keputusan di hadapan kaum laki-laki atau suaminya, hanya saja kekuasaan seperti ini belum diakui oleh dunia patrilineal. Namun bagi wanita Jawa, berada dalam kultur formal yang terhegemoni oleh kekuatan laki-laki tidak berarti kemudian mereka tidak mampu mempengaruhi keputusan-keputusan dalam publik. ${ }^{33}$ Wanita Jawa mengembangkan sebuah cara khas untuk mendapatkan kekuasaan dan tetap dapat mempengaruhi sektor publik tanpa meninggalkan atau melanggar nilai-nilai keutamaan kultur Jawa (prinsip keselarasan, hormat, dan terkendali). ${ }^{34}$

Di samping itu, hal yang menjadi penting lagi adalah memahami proses dalam upaya untuk memperoleh dimensidimensi feminitas sebagai faktor utama konstruksi kultur kekuasaan Jawa yang secara alami berkelindang, sehingga adanya kekuasaan wanita Jawa lebih didominasi oleh wanita Jawa. Adapun proses untuk memperoleh kekuasaan tersebut adalah dengan penaklukan dunia lahir (pamrih dan egoisme) dan pengembangan dunia dalam (bathin). Upaya ini merupakan proses penyadaran melalui 'rasa', yang merupakan penghalusan dan pendalaman rasa secara terus menerus untuk menaklukkan nafsu egoisme dan pamrih. ${ }^{35}$

'Rasa' dalam bahasa Indonesia mencakup arti secara fisik maupun emosional. Dalam bahasa Jawa, perkataan ini juga berarti "perasaan intuitif" (bisikan kalbu). Semakin tajam "rasa” seseorang, maka semakin dekatlah ia dengan sumber kekuatan yang hakiki (baca:kekuasaan). Ketajaman 'rasa' hanya akan dimiliki seseorang yang mempunyai ketahanan untuk menderita dan kemauan untuk selalu menaklukkan diri, yang diekspresikan dalam kecenderungannya untuk mengaku, mengayomi, mengalah, dan mengabdi. ${ }^{36}$

\footnotetext{
${ }^{33}$ B. Susanto, Citra Wanita dan Kekuasaan (t.k.p: t.n.p, 1992), 91.

${ }^{34}$ Novianto, Kuasa..., 208.

35Ibid.,210-1

36Ibid.
} 
Secara garis besar kemudian tampak bahwa wanita Jawa tidak perlu menjadi maskulin untuk mendapatkan kekuasaan, tetapi ia justru harus memanfaatkan kefeminitasnya, yakni berperilaku halus, mampu mengendalikan diri, dan menderita dalam semangat asketisme. Kekuasaan diperoleh dengan diam (tenang), pengendalian diri yang sempurna (ciri-ciri feminim) ketimbang aktif dan progresif. Gambaran ini tentu tak jauh dari gambaran ideal wanita Jawa.

\section{Catatan Akhir}

Keberanian peneliti untuk menggunakan metode konstruktif teoritis ini bisa diandalkan, meski metode ini menanggung resiko atau kerugian, karena realitas sosial-empiris dapat semakin menipis, bahkan hilang. Namun di samping sosial-empiris menipis, menurut penulis karakteristik keilmiahan dari penelitian ini juga akan diragukan, hal ini dikarenakan metode konstruktif teoritis ini dimaksudkan sebagai suatu skema atau struktur atau gambar yang tidak merupakan kesimpulan induktif dari data tertentu, tidak juga hasil suatu deduksi, tetapi dibangun atas dasar kepastian intuitif dengan tujuan untuk mencapai kejelasan logis, dengan harapan bahwa konstruksi itu akan membantu untuk memahami sesuatu dengan lebih baik.

Mengapa penulis sedikit menaruh optimisme dari metode penelitian ini? Karena peneliti mengimbangi bahaya itu , sebagai kontrol konstruksi teoritis tentang "kekuasaan wanita Jawa", maka studi ini memanfaatkan data ilmu-ilmu sosial empiris tentang masyarakat Jawa, di samping peneliti juga melakukan pengambilan data langsung di lapangan. Namun, hal itu tidak mengubah kenyataan bahwa bagaimanapun juga "kekuasaan wanita Jawa", orang Jawa dan masyarakat Jawa dalam penelitian ini tidak langsung menunjuk pada masyarakat Jawa yang nyatanyata ada, atau pernah ada atau untuk sebagian ada, namun sebaliknya jika peneliti mengambil sikap dengan mencari data di lapangan sebagai antisipasi bahaya metode konstruktif teoritis, 
maka yang menjadi pertanyaan besar, apakah mungkin dikatakan metode konstruktif teoritis lagi jika yang dilakukan peneliti adalah mengambil data dari lapangan yang sudah ditentukan sebelumnya, sehingga untuk apa metode konstruktif teoritis ini di gunakan dalam penelitian ini?

Menurut peneliti, munculnya persoalan gender ini diakibatkan konsep paternalistik yang secara formal hadir dalam pembagian peran laki-laki dan wanita. Konsep paternalistik itu bahwa istri adalah konco wingking yang asal mulanya dipengaruhi oleh konsep agama Islam dan Kristen, yaitu ketika Tuhan menciptakan manusia pertama, yang didahulukan adalah lakilaki, yaitu Adam, sesudah itu baru Hawa dengan jenis kelamin perempuan yang diciptakan dari rusuk Adam sebelah kiri. Hal ini seperti yang ditegaskan oleh Ester Boserup bahwa wanita melayu sebenarnya secara tradisional itu aktif, namun karena 'kedatangan Islam' dan pengaruh dari Inggris dan Belanda membantu menciptakan pola peran wanita yang lebih rendah dari laki-laki. ${ }^{37}$

Menurut penulis, peneliti seperti meng-iya-kan pernyataan Ester Boserup. Padahal pernyataan ini kental dengan nuansa pendiskritkan agama, karena tidak ada watak agama, baik Islam maupun Kristen yang mempunyai tradisi patriarki, Islam sendiri pada dasarnya mengakui kesamaan kedudukan laki-laki dan perempuan. Bahkan di dalam Islam terdapat perhatian khusus terhadap wanita. Karena itu, segala hal ihwal yang menyangkut hak wanita, al-Qur'an tidak pernah mendeskreditkannya dengan laki-laki (lihat Qs. 16 [al-Nahl]: 97). Kenyataan ini ditopang oleh fakta nyata bahwa penamaan surat dalam al-Qur'an sama sekali tidak dijumpai suatu surat yang secara khusus menonjolkan kaum laki-laki, misalnya terdapat suatu surat yang diberi label alRijâl (laki-laki). 
Secara substansial, Islam -sebagai suatu sistem ajaran dan pandangan hidup- sesungguhnya sarat dengan pesan-pesan untuk memuliakan wanita. Bahkan penting dikatakan bahwa baru satu abad yang lalu wanita Barat mencapai hak-hak mereka secara hukum melalui "Gerakan Women's Lib"-nya. ${ }^{38}$ Namun, lebih dari seribu tahun yang lalu (tanpa berapologi), jauh sebelum wanita Barat menemukan posisi haknya secara hukum, Islam telah memberikan hak dan menentukan kedudukan wanita secara hukum, Islam telah memberikan hak dan menentukan kedudukan wanita secara positif dalam konteks kemanusiaan secara universal. Ini tercermin tidak saja terungkap secara normatif dalam al-Qur'an, tetapi sudah menjadi tradisi dari perilaku Nabi Muhammad Saw. yang diikuti oleh masyarakat.

Sedangkan yang menjadi pemicu adanya bias gender adalah tafsir agama atau faktor para penginterpretasi agama yang cenderung patrilineal, hal ini dikarenakan penafsiran keagamaan yang tidak mustahil dipengaruhi oleh tradisi dan kultur patriarki, ideologi kapitalisme maupun pandangan yang lain-lainnya. ${ }^{39}$

\section{Daftar Pustaka}

B. Susanto, Citra Wanita dan Kekuasaan (t.k.p: t.n.p, 1992).

Christina S. Handayani dan Ardhian Novianto, Kuasa Wanita Jawa (Yogyakarta: LKiS, 2004).

Frans Magnis Suseno, Etika Jawa (Jakarta: Gramedia Pustaka Utama, 1996).

H. Eckstein dalam F. N. Kerlinger, Asas-Asas Penelitian Behavioral (Yogyakarta: Gadja Mada University Press, 1986).

${ }^{38}$ Syamsul Arifin dkk., Spiritualisasi Islam dan Peradaban Masa Depan (Yogyakarta: SIPRESS, 1996), 202-3.

39Penjelasan ini juga bisa dilihat Fakih, Analisis Gender..., 134-8. Lihat juga Muhammad Asad, The Message of The Qur'an (Giblatar: t.n.p, 1980), 933. 
M. Singarimbun, "Metode dan Proses Penelitian" dalam Masri Singarimbun dan Sofian Effendi, Metode Penelitian Survei (Jakarta: LP3ES, 1989).

Mansour Fakih, Analisis Gender dan Transformasi Sosial (Yogyakarta: INSIST Press, 2005).

Muhammad Asad, The Message of The Qur'an (Gibraltar: t.n.p, 1980).

Nana Nurliana Soeyono "Wanita Sebagai Pemimpin: Suatu Tinjauan Historis" dalam Wanita dalam Masyarakat Indonesia: Akses, Pemberdayaan, dan Kesempatan, ed. Atha Mudzhar (Yogyakarta: Sunan Kalijaga Press, 2001).

Nur Syam, "Perbedaan Penelitian Kualitatif dan Kuantatif", Makalah, disampaikan pada kuliah S3, semester I, konsentrasi Pemikiran Islam, IAIN Sunan Ampel Surabaya, 2008.

Syamsul Arifin dkk., Spiritualisasi Islam dan Peradaban Masa Depan (Yogyakarta: SIPRESS, 1996). 